\title{
Çeviri edimine dilbilimsel açıdan uygulamalı bir yaklaşım
}

\section{Meltem Merve KONU'}

\begin{abstract}
APA: Konu, M. M. (2019). Çeviri edimine dilbilimsel açıdan uygulamalı bir yaklaşım. RumeliDE Dil ve Edebiyat Araştırmaları Dergisi, (Ö6), 500-516. DOI: 10.29000/rumelide.649339
\end{abstract}

\section{$\ddot{\mathbf{O z}}$}

Çeviri; dil içi ya da diller arasında alıcı ve verici arasında sözlü veya yazılı enformasyon/ iletişimi sağlayan, amaca uygun göstergelerden oluşan eşzamanlı/ artzamanlı bir edimdir. Çeviri çalışmaları bilim, teknoloji ve edebiyat başta olmak üzere tüm alanlarda kullanılmaktadır. Bu alanlar arasındaki edebi çeviriler alıcının zevkinden akademik gelişimine kadar çeşitli amaçlara hizmet etmektedir. Bilindiği üzere, kaynak ve erek dildeki sözlü/ yazılı metin aynı ortam ve durumlarda kullanılabildiği ölçüde çeviri eylemi amacına ulaşmış olmaktadır. Bu nedenle, anlamsal ve işlevsel eşdeğerliğin sağlanması çevirinin temel amacıdır. Uygulamalı dilbilimin alanlarından biri olan çeviribilim çalışmalarında dilbilimsel eşdeğerliği oluşturabilmek, çeviri için bir nevi iskelet görevi görmektedir. Çevirilerde dilbilgisel, anlamsal ve işlevsel bütünlüğü sağlamak; çevirmenin ve çevirinin amacına ulaşması, alıcının da ortaya çıkan üründen gereğince yararlanabilmesi için önem taşımaktadır. Bu süreçteki en önemli sorun bilgi yitimidir. Bilgi yitimi; kaynak dilde yer alan biçimsel, sözdizimsel, sözlüksel, anlamsal ve biçemsel ögelerin tam olarak erek dildeki metne yerleştirilememesinden kaynaklanmaktadır. Çevirmenin amacı bilgi yitimini olabildiğince en aza indirebilmektir. Bu noktada, çevirmen Üretici Dönüşümsel Dilbilgisi başta olmak üzere birçok dilbilim kuram ve kavramlarından bilinçli/bilinçsizce yararlanmaktadır. Bu durumu örneklendirmek amacıyla çalışmada Edgar Allan Poe'nun "Annabel Lee” adlı şiiri Melih Cevdet Anday ve Uğur Demiröz tarafından Türkçeye çevirileri ile karşılaştırılarak dilbilimin yöntem, kuram ve kavramlarının çeviri edimindeki önemini ortaya koymak amaçlanmıştır. Bu amaçla, çeviri metinleri dilbilgisi, imge, anlam ve deyiş kayıpları ile işlevsellik açılarından eşdeğerlik olgusu çerçevesinde ve dilbilimin alt alanlarından biçimbilim, sözcükbilim, sözdizim ve anlambilim temelinde asıl eser ile karşılaştırmalı olarak incelenmiştir.

Anahtar kelimeler: Annabel Lee, çeviribilim, hedef dil, kaynak dil, uygulamalı dilbilim.

\section{An applied approach to translation performance in terms of linguistics}

\begin{abstract}
Translation is a simultaneous/diachronic performance, consisting of expedient signs and providing oral/written information/communication in intralinguistic/interlinguistic between receiver and giver. It's benefited from translation studies in all fields particularly science, technology and literature. Literary translations are utilised with different purposes from pleasure of the receiver to academic development. As known, when oral/ written text in source and target language is used at the same environment and state, translation act reaches its goal. So, enabling equivalence of semantic and funtional is the main purpose in the translation. Enabling linguistic equivalence is the main frame in translation studies being among the fields of applied linguistics. Providing unity of
\end{abstract}

1 Ars. Gör., Bursa Uludağ Üniversitesi, Eğitim Fakültesi, Türkçe ve Sosyal Bilimler Eğitimi, Türkçe Eğitimi ABD (Bursa, Türkiye), meltemmerve@uludag.edu.tr, ORCID ID: 000o-0002-1139-3474 [Makale kaylt tarihi: 09.10.2019-kabul tarihi: 20.11.2019; DOI: 10.2900o/rumelide.649339] 


\begin{abstract}
grammatic, semantic and functional is important for reaching the gaim of translator and translation and utilising from product for receiver in translations. In this process, the most important problem is information loss. Information loss results from not placing morphologic, syntactic, semantic and stylistic factors of source language to target language completely. The purpose of translator is to minimize information loss. At this point, translator utilises from many linguistic theory and concepts by conciously/unconciously primarily generative transformational grammer. For exampling this situaiton, revealing the importance of linguistics' method, theory and concepts in translation performance has been aimed by comparing Annabel Lee poem by Edgar Allen Poe with Turkish translations by Melih Cevdet Anday and Uğur Demiröz. For this purpose, translation texts have been evaluated by comparing with the main poem in terms of grammatical, imaginative and expression loss, semantic shifts and functionality within the frame of equivalence fact and based on the subfields of linguistics which are morphology, lexicology, syntax and semantics.
\end{abstract}

Keywords: Annabel Lee, translation studies, target language, source language, applied linguistics.

\title{
1. Giriş
}

\subsection{Dilbilim ve çeviri}

Dilbilim dili her yönüyle inceleyen bir bilimdir ve bütün eylemleri konu alan diğer bilim dallarıyla sıkı bir ilişki içerisindedir. 20. yüzyılın ikinci yarısında yeni buluşlar, akımlar ve inceleme alanlarıyla büyük aşama kaydeden dilbilim diğer bilimler arasında da seçkin bir yere sahip olmuştur. Alanlar arası sıkı ilişkiler ve gelişmeler sayesinde dilbilim farklı alanların uzmanlarının da çalışmalarında yer verdikleri geniş bir bilim durumuna gelmiştir (Aksan, 2007).

Çeviri olgusu, kaynak dildeki bildirileri biçemsel ve anlamsal eşdeğerliği sağlayarak erek dile aktarma işlemi olarak tanımlanabilir (Vardar, 1988). Diğer bir deyişle, kaynak dildeki göstergeleri erek dilde anlamsal-biçimsel bütünlere eşanlı ya da artanlı dönüştürme eylemidir. Bu eylemin amacı, dilsel ve dil dışı bağlamdan betiğin oluşturduğu kendine özgü bütünle bu bütünün değindiği dil dışı dünyadan doğan anlamı, deyiş özellikleriyle birlikte başka dile iletmektir (Vardar, 2001). Çeviri yapıtı çevirdiği şeyi gösterir; fakat yapıtta görünen çevrilenin kendisi değildir. Çeviri bir ilki başka bir ilkte göz önüne sermektir ve dil kurallarından başka kurala bağlı değildir. Çevrilen çeviri yapıtında tekrar çevrilmiştir, diğer bir deyişle çeviri çevirinin çevirisidir. Dil ile çeviri ayrılmaz bir ilişki içerisindedir. Çünkü dil denilen şey de bir bakıma çeviridir. Çeviri olmasaydı dil de özel varoluşunu yitirirdi. Bir deniz yolculuğu için mektupla ayırtılan yerin daha sonra telgrafla iletilmesi ya da bir haritayı ilgili dilde yorumlamak bile "haritaca" söylenenden bir çeviridir. Çeviri bir dile getirme sürecidir. Bu sürecin başarısı ise bir dilde görüleni başka dilde ifade etmeye bağlıdır. Benzerliklere hatta yer yer aynılıklara karşın çevrilen metin çeviri yapıtı ile özdeş olamaz. Aksi düşünülürse çeviri metni çeviri eyleminin ürünü değil demektir. Çeviri; çevrilen dilden bağımsız olduğu, erek dilin kendine özgü sözcük ve kuralları olduğu için iki metnin yansıttığı birbirini tutmaz. Bu nedenle çeviri, kaynak dilin dile getirdiğine vakıf olmakla birlikte erek dilin gereklerine de uymak zorundadır (Uygur, 1989).

Çeviri metinleri dilsel nesneler olduğu için dilsel yaklaşımlar gerektirirler. Bu noktada çeviri çalışmaları ve dilbilim yolları kesişen alanlardır, dilbilim çeviri çalışmalarını çeviri de dilbilimi 
kapsar, çeviri verileri dilbilimde, dilbilim verileri de çeviride kullanılabilir; çeviri çalışmalarındaki kuramsal bilgi ve kavramlar dilbilim için, dilbilim kuram ve kavramları da çeviri çalışmaları için önemlidir (Malmkjaer, 2005). Çeviride dil/biçem boyutunu önemseyen yapısal dilbilimciler çeviriyi biçimin korunması gereken bir eylem olarak tanımlarken, dilden soyutlanamayacak olan kültür olgusuna önem verenler içeriğin daha önemli olduğunu savunmuşlardır. Çeviri eleştirilerinde kullanılan iletişim, bağıntı, düz anlam, durum bağlamı, gönderim, yeterlik, yan anlam, yüzey yapı, derin yapı, söylem, dinamik eşdeğerlik, bağlaşıklık, bağdaşıklık, biçimsel eşdeğerlik, işlev, bireydil, düzsöz, edimsöz, etkisöz, amaçlılık, metinsellik, lehçe, bağlam, kesit, okunurluk, gösterge, sözeylem, metineylem gibi terimlerin hepsi çeviribilim çalışmalarının dilbilimden soyutlanamayacağını göstermektedir. Özellikle metin temelli çözümlemelerde dilbilim verilerinden fazlasıyla yararlanılmaktadır. Çevirinin dil içi ve dil dışı ögelerden oluşan çok yönlü dinamik doğası gereği değerlendirmede bilimselliği sağlamak için metnin yapısal, anlamsal ve edimsel boyutunu dilbilim olmadan temellendirmek olası değildir (Kocaman, 1993).

Çeviri ediminde de her alanda olduğu gibi sorunlarla karşılaşılması kaçınılmazdır. Nord'a (1993) göre, çeviri sorunları kaynak metin (kişisel biçem, genelleştirilemeyen içerik), edimbilimsel etmenler (önvarsayım, sunu, sözcük oyunları vb.), dil çiftleri (söz varlığı, sözdizimsel farklılıklar), kültür çiftleri (kültürel farklılıklar) gibi amaç ve kaynak dil arasındaki birtakım farklılıklardan kaynaklanmaktadır (akt. Stolze, 2013). Jakobson'a (1959) göre, çevirideki bu eksiklikler terminoloji, ödünç sözcükler, ödünç çeviriler, yeni oluşumlar, anlamsal kaymalar ve dolaylamalar aracılığıyla nitelik ve nicelik bakımından daha uygun hale getirilebilir. Erek dildeki dilbilgisel boşluklardan kaynaklı anlam da sözlüksel olarak çevrilebilir. Vardar'a (2001) göre, çeviri sorunlarının başında bilgi yitimi gelmektedir ve çevirmenin başlıca amacı bu yitimleri olabildiğince azaltmaktır. Bilgi yitimine neden olan başlıca etmen de her dilin evreni kendine özgü biçimde bölümlemesi, yorumlaması, kavramlaştırması ve dizgeleştirmesidir. Ona göre, çağdaş dilbilimin geliştirdiği yöntemler iki dili de iyi bilen çevirmenin çoğunlukla bilinçsiz biçimde uyguladığı bu işlemlerin zorluğa neden olduğu durumlarda bilinçli biçimde gerçekleştirilmesinin faydalı olacağını göstermektedir. Boztaş’a (1993) göre, dillerin kendine özgü yapıları ve birebir eşdeğerliği bulunmamaları gereği kaynak dildeki aktarım erek dilde biçimlendirilirken kaynak dilin dizgesel farklılığı nedeniyle ögelerin kısmen ya da tamamen erek dile yerleşememesinden dolayı bilgi kayılarının giderilmesi de olası değildir. Bu nedenle dilde gerekli dilsel yetileri kazanmamış, çeviri edinci ve deneyimine sahip olmayan kişilerin çeviri eyleminde bulunmaması gerekmektedir. Yoğun çelişkili, yanlış ve hatalı aktarımlar çevirilerin bilimsel eşdeğerlik, uygunluk ve yeterlik gibi özellikler açısından değerlendirilmesine imkân tanımamaktadır (Aslan, 2000). Yılmaz'a (2013) göre, çeviride biçimden yola çıkılarak anlam aktarılmalı, fakat bu anlam kaynak dildeki etkisini kaybetmemelidir. Anlamı aktarmak her zaman olanaklıdır, ancak anlam etkisini aktarmak zordur ve her zaman mümkün değildir. Aynı etki verilemese de kaynak dildeki anlamsal etkiye yaklaşılarak benzer etki oluşturulmaya çalışılmalıdır. Bu noktada, çeviri ve çevirmenden yazarın niyetini, iletileri ve isteklerini aslına uygun olarak çarpıtmadan yansıtması beklenir. Vardar’a (2001) göre, diller arası çeviri yapısal-düzeneksel, ekinseltoplumsal, tür ve düzey açllarından değerlendirilebilmektedir. Fakat bu etmenler çeviriyi kolaylaştırabilir de zorlaştırabilir de. Bu güçlüklerin aşılmasında ise ilgili dillere ve kültürlere hâkim olmanın yanı sıra kişisel beceri ve sezgiler de önemli yer tutmaktadır. 
Çeviribilim; yazılı ve sözlü çevirinin yapısını kuramsal ve uygulamalı olarak inceleyen bir dilbilim dalıdır. Çeviribilim; çevrilecek metni eksiksiz ve doğru anlamaya yardımcı olabilecek metindilbilim, tarih, sosyoloji, felsefe, filoloji, göstergebilim, edebiyat, karşılaştırmalı edebiyat gibi alanlarla da yakından ilgilidir ve bu alanlardan büyük katkılar almaktadır (Karaağaç, 2013). Çeviribilimin yönteminin geliştirilmesinde dilbilimin yöntemlerinin ve dilbilimcilerin bakış açılarının da önemli katkıları olmuştur. Aynı şekilde dilbilim de artsüremli çalışmaların karşılaştırılmasında çeviriden yararlanmaktadır. Ölü dillere ait belgeler var olduğu dönemde çevirileri yapılarak çözülmüştür. Günümüzde konuşucularını yitirmeye başlayan dillerin belgelendirilmesinde de çeviri dilbilime yardımcıdır. Dil edinci, çeviri edinci, iki dillilik vb. konular da dilbilim ve çevirinin ortak çalışma alanındadır. Bu nedenle, her iki alan da ortak verileri kendi yöntemleri ile yorumlayarak üzerinde çalışmaktadırlar (Çetinkaya, 2017). Dilbilimin inceleme nesnesinin «dil» çeviribilimin ise «iletişim» olduğu gerekçesiyle çoğu araştırmacı dilbilimin çeviribilime olan katkısının çeviribilim anlayışı ile ters düştüğünü belirtse de çeviri çalışmalarının dile dayalı olması gerçeği bu alandaki çalışmalarda dilbilimin bir biçimde var olduğunu ve olacağını göstermektedir.

\subsection{Edebi metinler ve çeviri}

Edebiyat; kolay tanımlanamayan ve içerisinde birçok türü barındıran bir üst türdür. Edebiyat çevirisi kapsamında incelenen türlerin başlıcaları düzyazı/ kurmaca çevirisi (roman ve öykü dâhil), şiir, tiyatro, sinema ve televizyon alanındaki görsel-işitsel çevirilerdir. Bu türlerin her biri farklı izlemler gerektirerek çevirmenleri farklı biçimlerde zorlar (Tahir Gürçağlar, 2019). Edebiyat metinleri bilgi verme amacından ziyade okuru duygulandırma ya da eğlenme amacı taşır. Gerçeği olduğu gibi yansıtma zorunluluğuna sahip olmadığı için de gerçekle ilgisi sorgulanamaz. Edebi metinlerde edebi dil kullanımı esas olduğu için çok anlamlılığa açık deyiş ve sözcüklere sıkça yer verilir. Bu nedenle; içerik, biçim ve biçem birbirinden soyutlanamayacak bütünlüğe sahip olmak zorundadır (Jones, 2009; Meyer, 1997 akt. Tahir Gürçağlar, 2019). Edebi çeviride çeviri metni yeniden üretilir. Çevirmen okuduğu metindeki tadı değerlendirip yorumlayarak okuru/dinleyeni ile paylaşma amacı güder. Farklı türdeki yazın çevirileriyle farklı görüş ve dünyaları erek dil toplumunun beğenisine sunar. Çevirmenin erek dile yaptığı çevirilerinde kullandığı yalın ve saf dil amaç dilin niteliğini, çevirinin kalıcılığını ve topluma katkısını gösterir (Baytekin, 2000).

Baytekin (2000) edebi çevirinin kaynak dile sadık kalırsa akıcı ve estetik değil, aslından biraz uzaklaşıp serbest ve erek dile bağlı olursa haz verici olduğu görüşündedir. Ona göre, bu tarz çevirilerde çevirmen genellikle kaynak metnin özüne önem verir. Bu nedenle, çevirilerde kültürel ve toplumsal dil özelliklerinin dikkate alınması, verilen karşıllkların ne denli örtüştüğüne önem verilmesi ve yazın çevirilerinin dil, kültür ve bilgi birikimi ile yapılması gerekmektedir. Göktürk'e (2019) göre, çeviri eyleminde hangi bilginin, hangi amaçla, hangi dilden, hangi dile, kimin için aktarıldığı önemlidir. Yazın metinleri bilimsel metinlerin aksine belirlenmiş kurallarla işleyen bir etkinlik değil yorum nitelikli özgün ürünlerdir. Fakat bu süreç asıl metnin güdümünde belirli sınırlar dâhilinde işlemektedir. Çevirmen kaynak metnin zihninde biçimlendirdiği bu kurmaca tasarımı erek dilde yeniden oluşturmak için farklı imgelemler tasarlamak zorundadır. Tüm bunlar da yazın metinlerinin çevirisi en zor tür içerisinde yer almasına neden olmaktadır. Uygur’a (1989) göre, edebi çevirilerde başarı salt dil bilgisi ve sanat değil ikisinin bir arada ustaca kullanılmasıyla sağlanır. 
Özek'e (2001) göre, edebi dilin dil düzleminde farklı bir dil oluşturduğu söylenebilir. Çünkü edebi dilde amaç iletişimi sağlamanın ötesinde dinleyici/okurda estetik haz uyandırmak olduğu için kullanılan dilde sapmalar, bağdaştırmalar, anlam olayları, betimlemeler ve simgeler yer alır. $\mathrm{Bu}$ nedenle edebi metinler çözümlenirken temel anlamdan hareketle sözcüklerin metindeki duygu değerine ulaşılır. Şiirde kullanılan sözcükler günlük dilde kullanılanlardan farklı değildir; fakat sesleri daha uyumlu ve sözcükler arası ilişkiler günlük dile göre daha az düzenlidir. Bu durum şiiri diğer yazın türlerinden farklı kılmaktadır. Vardar' a (2001) göre, çevrilen betik yazınsal dile bağlanıyorsa, çevirmenin ilgili dilin deyiş özelliklerine ve yan anlamlarına hâkim olması gerekmektedir. Şiir çevirisine gösteren ögelerinin (sesler ve bürünsel özellikler) dâhil olması nedeniyle çeviri zorlaşmaktadır. Gösterenleri bürün olgularıyla birlikte diller arası aktarmak hiçbir durumda olası değildir. Bu durumda yorumlama edimi devreye girer ve çeviri, gösterenlerin egemen olduğu anlamı içeren ve aşan özgün oluşturum eylemleriyle özdeşleşir. Başkan (1978) söz konusu dilce şiir gibi tümceden bağımsız biçimde sözcük bağları ve çağrışımlarına dayalı ise, çevirideki başarı oranının olası ve olanaksız arasında değişeceğini belirtmiştir. Çeviri yabancı dil bilgisine dayalı olması kadar çevirmenin ana dilini kullanmasına bağlı bir beğeni sorunudur da. Aynı yabancı dilin çeşitli biçimlerde çevrilebilmesi de bunu gösterir. Ona göre, anlamın doğru yansıtıldığı çeviriler başarılı, anlamın çarpık yansıtıldığı çeviriler başarısız, biçimin doğru aktarıldığı çeviriler aldatıcıdır. Anlamı yanlış olsa bile tümcelerin kurallara uygun olarak üretilmesi çevirinin başarısını göstermez. Hatta bu çeviri türü en tehlikeli çeviri olarak tanımlanmalıdır. Bir diğeri ise anlam doğru anlaşıldığı halde tümcelerin bozuk olduğu çeviridir. Bu çeviri de amacını tam olarak karşılamaz ve erek dil için başarılı bir çeviri sayılmaz.

Demiral ve Kaya (2013) sözcüklerin şiir sanatında, duyguların yazı ve sözle işlenmesi nedeniyle anlam kazandığını veya kaybettiğini belirtmiştir. Burada önemli olan sözcüklerin iletisini doğru anlayarak aktarabilmektir. Bu zorluk çevirmenlerin en çok zorlandıkları türün şiir çevirisi olmasına neden olmaktadır. Bu noktada çevirmenlerin yapması gereken çeviri yöntemlerine uyarak yöntemleri doğru biçimde kaynak ve erek metne uygulamaktır. Onlara göre, bu süreçte kaynak metinde olmayan ifadeleri erek metne eklemek çeviri etkinliği olarak görülmemelidir. Başaran'a (2013) göre, hiçbir çeviri kolay değildir, ancak söz sanatı bakımından en zengin, anlam bakımından en yoğun, çok anlamlılık ve mecaz anlamlılığın fazlasıyla kullanıldığı edebi bir tür olan şiirin başka bir dilde eşdeğerliğini sağlamak belki de en zor olanıdır. Bu noktada çok anlamlı ifadelerin bir dereceye kadar eşdeğerliği sağlansa bile şiirdeki ritim, vezin, kafiye, vurgu, tını, sözdizim vb. özellikler kaynak dile has olduğundan amaç dilde eşdeğerliklerini sağlamak kolay değildir. Ona göre, diller arasındaki yapısal, sözcüksel, biçimsel farklılıklar ve farklı dil ailelerine ait olma gibi etmenler çeviriye yön vermektedir. Bu nedenle, çeviri eyleminde amaca ulaşabilmek için dilbilimin alt alanları olan anlambilim ve sözdizimi tekniklerinden de yararlanılması gerekmektedir. Aksi halde çeviri kaynak metni yorumlama ve yeniden yazma ediminden öteye geçemeyecektir. Tahir Gürçağlar (2019) ise şiir çevirisinin diğer edebi metinlerin çevirisine göre üzerinde daha çok özenle durulması gereken bir tür olduğunu belirtmiştir. Anlam; içerik ve biçimden oluştuğu için biçim önemlidir. Ona göre, dünya edebiyatının önemli şairlerinin farklı dillerde de adlarını duyurabilmiş olmaları şiirin çevirisinin mümkün olduğunu göstermektedir. Connolly’e (1998) göre, biçim ve içeriğin ayrılmaz oluşu, en az çaba yasasına bağlılı̆̆ı, dilin çağrışımsal boyutunu esas alması nedeniyle çokanlamlılığa imkân tanıması, kendine özgü bir ritminin olması gibi özellikler şiir çevirisini diğer edebi türlerin çevirilerinden farklı kılarak kendine has izlemler geliştirmesini gerektirir (akt. Tahir Gürçağlar, 2019). 
Özdemir (2014) şiirin çevrilebilirliğinin mümkün olup olmadığının sürekli tartışılan bir konu olduğunu belirtmiştir. Ona göre, düz yazıdan farklı olarak imgelerle, yan anlamlarla örülü olması, kendine has biçimsel farklılıkları barındırması ve kültürel ögelerin yer alması şiir çevirisini zorlaştıran etmenlerdir. Bu nedenle şiiri şiir kılan özellikler çeviride kaybolmaktadır. Ozek (2001) şiir dilinin, şairin dili bireysel kullanımı ile oluştuğunu belirtmiştir. Saussure’ün söz, Chomsky'nin edim terimleriyle belirttiği bu bireysel kullanımlarla günlük dildeki sözcüklerle yeni sapmalar, vurgular ve imajlar oluşturulmaktadır. Ona göre, edebi dilde yazarın genel dili bozmadan estetik kaygıyla oluşturduğu bu kullanımlar dile zenginlik katmakta ve bu da metinlerin anlaşılabilmesi için yorumlanmasını gerektirmektedir. Çünkü edebi metinlerde ortak duyuşlar edebi dil kullanılarak farklı imgelerle temsil edilmektedirler. Köksal'a (2008) göre de şiir çevirisi yaparken erek dildeki sözcük oyunlarının, ölçülerin, ritmin, yinelemelerin ve tekrarların seçimi oldukça önemlidir. Şair önce bireysel sesini temsil eden şiirin iç sesini yakalamalıdır. Diğer deyişle, sözcüklerin düz anlamlarının dışında şiirde yansıtılmak istenen anlamlarını yakalaması gerekir. Yoksa çeviri çeviri kokar ve işlevselliğini kaybeder.

Jakobson'a (1950) göre, şiirler sözcükler ve tümcelerden oluştuğu için şiir dilinin incelenmesi her alandan önce dilbilimin görevi ve yetkinlik alanındadır. Şiir dili ve çözümlemesi konusunda 1900'lü yılların başlarında Rusya'da dilciler tarafından oluşturulan Rus biçimciliği önemli bir akımdır. Şiirin çözümlenmesinde dilbilimin kılavuzluğunu esas alan bu okulda Şklovski, Tomaşevski, Vinogradoff gibi araştırmacılar şiiri ortaya çıkaran ögeler üzerinde durmuşlardır. Prag dilbilim okulundaki R. Jakobson da şiir dili üzerine incelemelerini sürdürmüş ve dilbilimin dil yapısının tümünü incelemesi nedeniyle yazın incelemelerinin de dilbilimin ayrılmaz parçası olduğunu belirtmiştir (akt. Aksan, 2016).

Şiir çevirisinde kullanılan yedi izlemi André Lefeveré şu şekilde belirtmiştir: Anlam ayırt edilmeden kaynak metne bağlı kalınan birebir (sözcüğü sözcüğüne) çeviri, kaynak metindeki ölçüyü aktarma amacı güden ölçülü (ölçübirimsel) çeviri, biçimsel özelliklerin ötesinde anlama öncelik veren şiirin düzyazı (nesir) olarak çevirisi, içeriğin ve anlamın ölçü ve uyak gibi biçimsel özelliklerin önüne geçtiği serbest koşuk çevirisi (uyaksız çeviri), ölçü ve uyağı temel alan uyaklı çeviri, kaynak metindeki sessel özelliklere öncelik veren sessel (sesbirimsel) çeviri, anlamın korunduğu fakat biçimin yeniden yapılandırıldığı yorumlama (Köksal, 2008). Edebi metinlerin çevirisi çoğu araştırmacının da belirttiği gibi en zor çeviri türü olarak bilinmektedir. Dillerin doğası gereği her dilin her durumu aynı biçimde yansıtamaması yazın çevirilerini zorlaştırmaktadır. Bu nedenle çevirmenler birtakım yöntemlerle kaynak dildeki etki ve işlevselliği erek dile olduğu kadarıyla aktarmaya çalışmaktadırlar. Bu sürecin sonunda ortaya çıkan ürünün de noksanlıklardan arınmış olmasını beklemek olası değildir. Bu bağlamda edebi çevirilerde birebir eşdeğerliğin beklenemeyeceği açıtıtır. Bu sebeple, aslına en yakın çeviriler yeterli ve kabul edilebilir düzeyde değerlendirilmektedir.

\section{3. Üretici-dönüşümsel dilbilgisi ve çeviri}

Çevirmen dilsel nedenlere özgü güçlükler noktasında sözdizimsel-anlamsal, biçimselsözdizimsel ve deyişbilimsel sorunlarla karşılaşmaktadır. Çevirmenin amacı da diller arasındaki ayrılıkları olabildiğince en aza indirgeyerek kaynak ve erek bildiri arasındaki eşdeğerliği sağlamak olduğu için, bu süreçte yapılacaklar üretici dönüşümsel dilbilgisi modelinden yola çıkarak saptanılırsa daha geçerli çözümlere ulaşılacaktır. Bu da kaynak dilin 
yüzey yapısından, gerçekleşmiş tümce ve bildirilerden hareketle derin yapıya, mantıksalanlamsal temel ulamlara inmeyi, buradan hareketle erek dilin eşdeğerli yüzey yapısına ulaşmayı gerektirmektedir. Bu işlemler anlama ve anlatma süreçlerine ilişkindir. Çevirinin özünde amaç yalnızca bildiriyi çözmek ya da anlamak değil, anlananı yeniden düzenleyerek uygun biçimde anlatmak, derin yapıdan erek dilin yüzeysel yapısına geçerken dilsel düzeneğin gerektirdiği dönüştürümleri gerçekleştirmektir. Her dilin yüzeysel yapısına değişik dönüştürüm süreçlerinden geçilerek varılması, eşdeğerlik olgusunun çok ayrı biçimlere bürünebileceğini ortaya koymaktadır (Vardar, 2001). Noam Chomsky'nin Üretici-Dönüşümsel Dilbilgisi kuramına göre tümceler sözdizimsel açıdan yapı ve dönüşüm kuralları dâhilinde oluşturulmakta ve çözümlenmektedir. Burada, yapı kuralları basit tümcelerin oluşumunu ifade ederken, dönüşüm kuralları karmaşık tümcelerin derin yapıdan yüzeye tek tümce olarak çımması ile ilgilidir (Aydın, 2017). Bu duruma örnek olarak Bebek yeni doğmuştu ve Bebek süt içiyordu tümcelerinin Yeni doğan bebek süt içiyordu biçiminde tek bir yargıya dönüşmesi ama temelde iki yargıyı bildirmesi durumu verilebilir. Hengirmen (1999) ÜDD’nin bireyin doğuştan getirdiği evrensel düzeneği ortaya koyma amacı taşıan bir dil bilgisi modeli olduğunu görüşündedir. Chomsky; her dilin temelde evrensel bir mantık çerçevesinde oluştuğunu, bir dilin kendi içerisindeki üretkenliğini ve yüzey yapıların derin yapılardan farklı olabileceğini özellikle belirterek bu modelin çeviride bir yöntem olarak kullanılamayacağını belirtse de (Gentzler, 1993 akt. Yazıcı, 2005) göstergebilimin ve çeviri kuramının devingen işleyişi nedeniyle onun uyarısı basite indirgenerek, kuram dil öğrenimi gibi çeviri kuramları ve eğitiminde de hâlâ kullanılmaktadır (Yazıcı, 2005).

ÜDD sayesinde bir çekirdek tümce edilgen, olumsuz, soru gibi farklı biçimlere dönüştürülebilir. Bu süreçte, derin yapıdaki tümcelerin yüzey yapıya aktarılmasında dilbilimin alt alanlarından (sesbilim, biçimbilim, sözdizim, sözcükbilim ve anlambilim) yararlanılmaktadır. Dilin sese dönüssen tümcelerinde gerekli ses uyarlamalarının belirli kurallar dâhilinde gerçekleşmesi sesbilimin; sözcüklere kural temelli birleştirilen ekler biçimbilimin; sözcüklerin dilin kuralına göre diziliş birlikteliği ve dilbilgisi kuralları sözdizimin; sözcüklerin niteliklerine göre seçimi sözcükbilimin; sözcüklerin hangi bağlamlarda hangi sözcüklerle bir arada bulunabileceği anlambilimin ÜDD’ye katkılarıyla gerçekleşmektedir (Aksan, 2007). Tüm bu dilbilimsel olanaklar bilinçli/bilinçsiz biçimde çevirmenler tarafından çeviri ediminde kullanılmaktadır. Bu da ÜDD’nin çeviriye katkısını göstermektedir. Vardar’a (1990) göre de çevirmen kaynak dille kurmak istediği eşdeğerlik olgusunu üretici-dönüşümsel dilbilgisi kuramından yola çıkarak oluşturmalıdır. Bu süreçte, kaynak dilin yüzey yapısında somutlanmış tümce ve bildiriden hareketle derin yapıdaki mantıksal-anlamsal düzeye inerek erek dilin yüzey yapısında benzer anlamı da oluşturması gerekmektedir (akt. Boztaş, 1993). Özetle, her türlü dil üretiminin ÜDD çerçevesinde gerçekleşmesi anlam olaylarının en çok yer aldığı yazın eserlerinin/çevirilerinin ÜDD'den soyutlanamayacağını göstermektedir. Özellikle kurmaca anlatıların dilbilimsel incelemelerinde dil/söz/anlam üretiminin derin ve yüzey yapıdan oluşan çok katmanlı yapısı gereği ÜDD çözümlemelerinin göz ardı edilmesi olası gözükmemektedir.

\section{4. Çeviride eşdeğerlik olgusu}

Eugene Nida, 1940'lı yıllardan itibaren İncil çevirisi üzerine çalışan ve bu deneyimini Chomsky'nin üretici-dönüşümsel dilbilgisi kuramıyla birleştiren bir araştırmacıdır. Hâlâ çeviribilimin kurucuları ve saygın isimleri arasındadır. Nida, İncil'in yerli topluluk dillerine 
yapılmış çevirilerinde antropolojinin dili etkilediği ve dilin kültürden soyutlanamayacağı sonucuna vararak, sözcükleri kültürel değerlerin simgesi olarak tanımlamıştır. Her toplumun farklı kültür olgularına sahip olması nedeniyle de çeviride eşdeğerliğin mümkün olmadığını savunmuştur. Ona göre, çeviride anlam ve biçem açısından kaynak metne en yakın sözcük ve deyiş kullanılarak eşdeğerlik sağlanabilir (Snell Hornby, 2006 akt. Tahir Gürçağlar, 2019). Nida'ya göre biçimsel ve devingen olmak üzere iki tür eşdeğerlik vardır: şiir sanatını şiir sanatına, kavramı kavrama, tümceyi tümceye aktarmak biçimsel eşdeğerliği sağlamak iken; kaynak dildeki iletiyi uygun kültürel bağlamda hedef kitleye aktarma eyleminde doğal etkiyi oluşturmak devingen eşdeğerliktir (Nida, 1964 akt. Karavin, 2016). Devingen eşdeğerlik, kaynak metin ile okur arasındaki ilişki erek metin ve okur arasında sağlandığı takdirde gerçekleşir. Bu süreçte erek dilde doğallığı sağlamak ve erek kültüre uygun bir aktarım yapmak önemlidir. Nida, 1970'li yıllarda çeviride erek kültürün önemini ve kaynak metne sıkı sıkıya bağlı kalmamak gerektiğini vurgulayan ilk çeviribilimcilerden biridir (Nida, 2000 akt. Tahir Gürçağlar, 2019). Nida'nın çalışmaları erek kültürde oluşturulması öngörülen etki (işlev) olgusunun bir ölçütü olmaması nedeniyle alan araştırmacıları tarafından eleştirilmiştir.

Eşdeğerlik dilin temel sorunu ve dilbilimin de önemli bir konusudur. Sözlü dilin herhangi bir alıcısı gibi dilbilimci yorumcu olarak eylemde bulunur. Fakat hiçbir dilsel örnek aynı sistemin farklı göstergeleri ya da farklı sistemdeki göstergeler içerisinde göstergelerin çevirisi olmadan dilbilim tarafından yorumlanamaz. İki dilin karşılaştırılması karşılıklı çevrilebilirliklerinin incelenmesini içerir; bu açıdan diller arası iletişimin yaygın uygulaması, özellikle çeviri etkinlikleri dilbilim tarafından daima denetim altında tutulmalıdır. Amaç ve kapsamı yansıtan bütün karşılıklı birimlerin tanımı ve farklı iki dilli sözlüklerin kuram ve uygulamasının önemi ve gereği göz ardı edilmemelidir. Aynı şekilde nelerin bir araya gelebileceği, dilbilgisel kavramların sınırlandırması ve seçiminde iki dili nelerin farklılaştırdığını tanımlanmalıdır (Jakobson, 1959). Jakobson (2000) iki farklı dilde kullanılan sözcüklerin anlamsal açıdan birbirine eşdeğer olamayacağı görüşündedir. Bu nedenle ona göre çeviride en büyük sorun eşdeğerliktir. Bu noktada, dillerin farklı olmaları çeviriyi imkânsız kılmamakta ve anlam farklı biçimlerde aktarılabilmektedir (akt. Tahir Gürçağlar, 2019). Boztaş'a (1993) göre, çeviri salt kaynak ve amaç dil arasındaki sözcüksel ve dilbilgisel eşdeğerliğin ötesinde kaynak dildeki deyişi; kültür, anlam ve işlevselliği en doğal biçimde aktarabilmektir. Bu nedenle, eşdeğerlik teriminden aynılık anlamı çıkarılmamalıdır. Çünkü sözlerin anlamı, kullanımı ve işlevleri arasında örtüşme olduğu takdirde aynılık olgusundan bahsedilebilir. Kocaman (1993) da çeviride eşdeğerlik olgusunun metinsel, biçimsel, kaynak metin odaklı, içerik ve ileti düzlemleri olmak üzere çeşitli boyutlarda ele alınması gerektiğini belirtmiştir.

Anton Popovic çevirinin amacının güzel ve anlıksal değerleri diller arasında aktarma amacı taşıdığını dile getirirken biçemsel eşdeğerliğin önemini vurgulamıştır ve eşdeğerliği çeviriler arasında sözcük düzeyinde sağlanan eşdeğerlik olan dilsel eşdeğerlik, kaynak ve erek metin arasındaki sözdizimsel veya dilbilgisel eşdeğerlik dizisel eşdeğerlik; erek metnin kaynak metindeki anlamını koruyarak işlevsel eşdeğerliği sağlaması biçemsel eşdeğerlik; erek metnin biçim ve şekil bakımından kaynak metinle olan metin düzeyindeki tutarlığı metinsel eşdeğerlik olmak üzere dört boyutta ele almıştır (Popovic, 1970 akt. Yazıcı 2005). Popovic biçimsel eşdeğerliğin önemini, Kade ise içerik düzeyinde eşdeğerliğin gerekliliğini savunmuştur (Reiss ve Vermer, 1984; Kade, 1968 akt. Köksal, 2008). Werner Koller ise eşdeğerliğin yanı sıra denklik kavramı üzerinde durmuştur. Ona göre, denklik kaynak ve erek dildeki benzerlik ve farklılıklar üzerinde kuruluyken; eşdeğerlik erek metne eşdeğer biçimde yansıyan sözcük ve sözcük 
gruplarını temsil etmektedir. Koller; çeviri metni çözümleme sürecinde metnin işlevi, içeriği, biçimsel-estetik özellikleri, dilsel-biçimsel özellikleri ve edimsel özelliklerine dikkat edilmesi gerektiğini belirtmiştir (Munday, 2001 akt. Tahir Gürçağlar, 2019). Koller; eşdeğerliğin içeriğin değişmediği, sözcük, tümce ve metin düzeyindeki benzerlik olan düzanlamsal eşdeğerlik; özgün dilsel yapı gösteren metinler için geçerli yananlamsal eşdeğerlik; amaç dilin kural ve geleneklerine uyan yapı ile metni aktaran metinsel eşdeğerlik; amaç dilin dilsel kullanım özelliklerinin erek dile uygulanmasıyla sağlanan iletişimsel denklik olan edimsel (dilkullanımsal) eşdeğerlik; kaynak metnin sözdizim ve biçem özellikleri ile kendine özgü anlatımını benzer etki sağlayabilecek biçimde aktaran biçimsel eşdeğerlik olmak üzere beş boyutundan bahsetmiştir (Koller, 1979 akt. Göktürk, 2019). Koller’in kaynak metinle birlikte çeviride metin dışı ögeler ile edimsel eşdeğerliğe yer vermesi çeviride devingen ilişkilere, çevirinin erek dil ve metin bağlantısına verdiği önemi göstermektedir (Yazıcı, 2005).

Çevirinin tamamında eşdeğerlik üzerine bir yorum yapabilmek için tüm bu eşdeğerlik türlerinin asıl metin ve hedef metin arasında bir arada uyum içerisinde var olması gerekmektedir. Dolayısıyla çeviri metinlerin kaynak metinle olan anlamsal ve işlevsel örtüşmelerinin tek bir eşdeğerlik açısından değerlendirilerek yorumlanması olası değildir. Stolze (2013) de bu konuda eşdeğer çevirinin olanaklı olmadığını, fakat erek metnin kaynak metnin eşdeğeri sayılabileceğini belirtmiştir. Ona göre, dil ve kültür farklılıkları nedeniyle farklı düzlemde yer alan unsurlar genellikle değişmeyeceği için tümüaynı anda eşdeğer olarak kabul edilemez. Dolayısıyla hiçbir çeviride özellikle edebi çevirilerde \%10o eşdeğerlikten söz edilemez. Çeviriye kültürel açıdan yaklaşan ve çeviri metinlerini dilsel ögelerden çok kültürel ve toplumsal etmenlerin biçimlendirdiğini savunan araştırmacılar eşdeğerlik olgusunu eleştirmektedirler (Tahir Gürçağlar, 2019). Fakat Ülsever'e (2007) göre dilbilimde değişik anlam türlerinin var olması çeviri metinlerde değişik düzey ve yoğunlukta eşdeğerlikler bulunduğunu göstermektedir. Özetle, eşdeğerlik konusunda araştırmacıların görüşleri kendilerine göre doğru olan nedenlerle farklılaşsa da yapılan çalışmalar çeviride başarı ölçütünü değerlendirmenin metnin kaynak dildeki etkiyi erek dile taşıması gerçeğine dayalı olması nedeniyle eşdeğerlik olgusunun göz ardı edilemeyeceğini ve etkisinin uzun süre daha tartışılacağını göstermektedir.

\subsection{Sapmalar ve deyiş kayıpları}

Sapmalar, yazın incelemelerinde değerlendirilen dilbilimsel olaylardır. Aksan (2016) bu sapmaların değişik amaçlarla dildeki göstergelerin ses açısından değiştirilmesiyle sesbilimsel; eylem çekimlerinde, sözcüklerin başka sözcüklerle bağdaştırılmasındaki beklenmeyen kullanımlara başvurulmasıyla biçimbilimsel; biçimbirimlerin yeni birleşimler içerisinde yeni ögelerin türetilmesi için kullanılarak dilde bulunmayan göstergelerden yararlanılmasıyla sözcükbilimsel; sözcüklerin sıraları değiştirilerek kullanılmasıyla sözdizimsel; kalıplaşmış sözcüklerin bağdaştırılma biçimleriyle oynanarak daha önce kullanılmamış türetme ve birleştirmelere, alıcıların zihninde değişik tasarım ve imgeler oluşturulmasına yönelinmesiyle anlambilimsel düzeyde gerçekleştiğini belirtmiştir.

Çeviri edimindeki diğer dilbilimsel olay da deyiş kayıplarıdır. Popovic, deyiş kaymasını dil dizgelerinin farklılıklarından kaynaklanan yapısal kayma, konu nedeniyle metin türünün farklılaşması türsel kayma, çevirmenin bireysel dil kullanım farklılıklarından kaynaklanan bireysel kayma, çevirinin yanlış anlamaya yol açması olumsuz kayma, iki dil arasındaki 
farklılıklar nedeniyle çevirmenin farklı anlamlara başvurarak konunun değişmesine neden olan konusal kayma olmak üzere beş türde incelemiştir (Karantay ve Salman, 1987; Bassnett, 1990 akt. Yazıcı 2005). Popovic'e göre kaynak metne göre yeni sayılabilecek her eksiltme ya da ekleme deyiş kaydırması kapsamındadır ve bu kaydırmalar diller arası farklılıklardan kaynaklanıyor ise zorunlu; çevirmenin bilinçli/bilinçsiz tercihi ile oluşuyorsa isteğe bağlı kaydırmalardır. Ona göre, çeviri ediminde kaynak metin esastır ve deyiş kaydırmaları da kaynak metni daha iyi aktarmak amacıyla ortaya çıkmaktadır (Tahir Gürçağlar, 2019). Popovic, metnin anlatımsal kimliğini korumak ve işlevselliği sağlamak amaciyla çevirmenin sözcük düzeyinde eşdeğerliği göz ardı edebileceğinden de bahsetmiştir. Ona göre, çevirinin amacına ulaşması biçemsel eşdeğerliğin sağlanması ile mümkündür ve bu amaçla çeviride deyiş kaydırmalarına başvurulması bir yitim değildir. Aksine bu çevirmenin yapıtın bütünlüğünü korumak amacıyla devingen yöntemleri kullandığını göstermektedir (Bassnett, 1980 akt. Yazıc1, 2005).

Eşdeğerliği metinsel ve biçimsel açıdan ele alan J.C. Catford'a göre çeviri biçimsel olarak denk değilse çeviri kayması olmuş demektir. Catford "kaydırma" kavramını ilk kez gündeme getirmiş ve kaydırmaların kaynak dilde dilbilgisi düzeyinde verilen anlamın erek dilde sözcük düzeyinde verilmesi ya da tam tersi durumda oluşan düzey kayması; sözcük sınıfları (sıfatken isim olarak çevrilmesi), dilsel hiyerarşi (tümcenin tamlamaya ya da sözcüğe dönüşmesi) ve sistemler arası kaymalardan (tekil-çoğul ilişkileri) oluşan dilbilgisel (kategori temelli) kaymalar olmak üzere ikiye ayırmıştır (Munday, 2001; Cattford, 2000 akt. Tahir Gürçağlar, 2019). Delibaş ve Delibaş (2017) çevirilerde kaynak metne sadık kalabilmek amacıyla erek okuru zorlayan ifadelerin kullanılabildiğinden bahsetmiştir. Özellikle ekleme ve eksiltme yöntemleri çeviri eserlerde sıklıkla tercih edilmektedir. Metnin akıcılığını erek dilde sağlayabilmek amacıyla bu yöntemlere çevirmenler sıkça başvurmaktadır. Onlara göre, akıcılığı sağlamak amacıyla da olsa kaynak metinde olmayan ifadeler erek metne yerleştirilirken asıl metnin anlamsal yapısına da sadık kalınması gerektiği unutulmamalıdır. Özetle, sapmalar ve deyiş kayıpları konusunda araştırmacıların görüşleri farklılık gösterse de yazın eserlerinin dilbilimsel açıdan uygunluğunun değerlendirilmesinde bu iki etmen kullanılmaktadır ve kullanılmaya da devam edeceği düşünülmektedir.

\section{2. Çeviri türleri ve yöntemleri}

Çeviri türleri ve yöntemleri ile ilgili araştırmacıların pek çok farklı sınıflandırması bulunmaktadır. Bunlardan bazıları şu şekildedir:

Jean-Paul Vinay ve Jean Darbelnet (1958) sözcüğ̈̈ sözcüğüne ve anlamına göre olmak üzere iki çeviri türünden bahseder. Buna göre, sözcüğü sözcüğüne çeviri kaynak dildeki metnin erek dilin dil yapısı ile uyumlu olarak yeniden aktarılması iken; anlamına göre çeviri kaynak metnin amacına uygun olarak, biçimsel örtüşmeden ziyade içeriğinin yansıtılmaya çalışıldığı çeviridir ve daha çok edebi metinlerde kullanılmaktadır (Akt. Köktürk, 2015). Jakobson (1959) çeviri türlerini dil içi, diller arası ve göstergeler arası olmak üzere üçe ayırmıştır. Buna göre dil içi çeviri aynı dildeki farklı göstergeler aracılı̆̆ıyla yorumlayarak açımlama; diller arası çeviri farklı dillerdeki sözlü göstergeleri yorumlama; göstergeler arası çeviri sözlü olmayan gösterge sistemleri aracılı̆̆ıyla kaynak metni yorumlama edimidir. J. House (1997) iki tür çeviriden söz etmiştir: Buna göre hedef kitleye dolaylı olarak seslenen çeviri açık çeviri iken; okuyucuya doğrudan seslenen metin ise örtük çeviridir. Açık çeviride okuyucu/ dinleyici çeviri metni 
okuduğunun farkındayken, örtük çeviride bu ayırda varamaz (akt. Yazıcı, 2005). Newmark ise anlamsal ve iletişimsel olmak üzere iki çeviri türünden bahsetmiştir. Ona göre, kaynak dil odaklı çeviri sözcüğü sözcügüne, erek dilin izin verdiği ölçüde söz dizimsel eşdeğerlik esashı, kaynak metne sadık ve kaynak metnin anlamını yansıtmaya dayalıyken; erek dil odaklı çeviri metnin erek dile uyarlanması, herhangi bir bağlılık içermeyen, erek dildeki deyişleri temel alan ve erek dilde iletişimi sağlama amacı güden bir çeviridir.

Vinay ve Darbelnet İngilizce ve Fransızca dilini karşılaştırdıkları çalışmalarında doğrudan (sözcüğü sözcügüüe) ve dolaylı (serbest) çevirinin dilbilimsel açıdan belirli aşamalar dâhilinde gerçekleştiğinden bahsetmişlerdir (Munday, 2001 akt. Tahir Gürçağlar, 2019). Bu noktada doğrudan çeviri; sözcüğü sözcügüne çeviri, ödünç alma ve öyküntü yöntemleriyle; dolaylı çeviri ise eşdeğerlik, uyarlama, zorunlu ya da isteğe bağlı yer değiştirme ve zorunlu ya da isteğe bağlı modülasyon yöntemleriyle gerçekleşmektedir (Vinay ve Darbelnet, 2000 akt. Tahir Gürçağlar, 2019). Köktürk (2015) de bu çeviri izlemlerine ek olarak açımlama, anlamına göre çeviri, yer değiştirme, standart hale getirme, perspektif kaydırma, daraltma/genişletme, anlamsal çeviri, iletişimsel çeviri, doğallaştırma, eksiltme, güncelleştirme, basitleştirme ve bölümleme gibi yöntemlerden bahsetmiştir.

\section{Annabel Lee hakkinda}

“Annabel Lee”nin Amerikalı şair ve yazar Edgar Allan Poe'nun 1849 yılında yazdığı son şiiri olduğu ve vefatının hemen ardından yayımlandığı bilinmektedir. Çoğu şiiri gibi bu şiirin teması da güzel bir kadının ölümüdür. Şair, gençlik döneminde Annabel Lee'ye meleklerin bile kıskanacağı güçlü bir aşkla tutulmuştur. Öyle ki, sevgili öldükten sonra bile anlatıcının aşkı bitmez. Lee'nin gerçekliği konusunda farklı görüşler olsa da en baskını Poe'nun eşi Virginia Eliza Clemm Poe olduğu görüşüdür. Anlatıcı yıllar önce isimsiz bir deniz ülkesinde Lee’ye âşı olmuştur. Çok genç olmalarına rağmen aşkları öylesine tutkuludur ki melekler bile onları kıskanır ve kötü cinlerin gücü bile onların ruhlarını birbirinden ayırmaya yetmez. Lee, onları kıskananlar tarafından göze geldiği için ölür. Fakat anlatıcı, Lee'nin gözlerinin parlaklığını yıldızlara bakarak yaşamaya devam eder ve böylelikle aşkları sonsuzluğa ulaşır. Her gece onu hayal eder, deniz kenarındaki mezarına giderek orada sabahlar. Çünkü bir gün orada aşkına tekrar kavuşacağına inanmaktadır. İçerik açısından şiirin hüzünlü doğasını Türk edebiyatında Abdülhak Hâmit Tarhan’ın “Makber” şiiri ile özdeşleştirmek mümkündür.

\section{Amaç}

Çalışmanın amacı “Annabel Lee” adlı şiirin Melih Cevdet Anday ve Uğur Demiröz tarafından Türkçeye uyarlanmış çevirileri ile kaynak metin karşılaştırılarak dilbilimin yöntem, kuram ve kavramlarının çeviri edimindeki önemini ortaya koymaktır. Bu amaçla metinler; biçimbilimsel (dilbilgisel), sözdizimsel, sözcükbilimsel, imgesel ve deyiş kayıplarını yansıtıp yansıtmaması; anlambilimsel kaymaları içerip içermemesi ve kaynak dildeki işlevselliğiyle örtüşüp örtüşmemesi açısından asıl eser ile karşılaştırmalı olarak incelenmiştir.

\section{Yöntem}

Çalışmada nitel araştırma yaklaşımı kullanılmıştır. Veriler Anday için https://www.siir.gen.tr/siir/e/edgar_allan_poe/annabel_lee.htm adresinden; Demiröz 
için

https://www.siirleraslabitmemeli.com/annabel-lee-edgar-allan-poe-siir-cevirisi/ adresinden doküman incelemesi tekniği ile toplanmıştır. Doküman incelemesi "araştırma problemiyle ilgili yazılı ya da görsel malzeme veya materyallerin belirli amaçlar doğrultusunda değerlendirilerek yorumlanmasıdır" (Yıldırım ve Şimşek, 2011). Toplanan veriler Aksan'da (2007) yer alan dilbilim alt alanlarından oluşturulan ölçütler dâhilinde betimsel analiz ile çözümlenmiştir. "Betimsel araştırmalar incelenen olay, olgu veya durumu dikkatli ve tam biçimde tanımlayabilmeyi amaçlar" (Büyüköztürk vd. 2016). Sonraki aşamada bulgular dilbilim terimleriyle açıklanarakyorumlanmıştır.

\section{Bulgular}

\begin{tabular}{|c|c|c|}
\hline Melih Cevdet Anday (1915) & Edgar Allen Poe (1849) & Ŭ̆ur Demiröz (?) \\
\hline Senelerce senelerce evveldi & (1)It was many and many a year ago & Çok değil bir yll öncesinde \\
\hline Bir deniz ülkesinde & (2)In a kingdom by the sea & Ülkesi deniz kenarında \\
\hline $\begin{array}{l}\text { Yaşayan bir kız vardı bileceksiniz } \\
\text { (orada) }\end{array}$ & $\begin{array}{l}\text { (3)That a maiden there lived whom } \\
\text { you may know }\end{array}$ & $\begin{array}{l}\text { Bir kiz vardı orada, kimbilir } \\
\text { kimlerle yaşamış }\end{array}$ \\
\hline İsmi Annabel Lee & (4)By the name of Annabel Lee & $\begin{array}{l}\text { Ah Annabel Lee adın dillere } \\
\text { dolanmış }\end{array}$ \\
\hline $\begin{array}{l}\text { Hiçbir şey } \\
\begin{array}{l}\text { düşünmezdi } \\
\text { saşamak, ile) }\end{array}\end{array}$ & $\begin{array}{l}\text { (5)And this maiden she lived with no } \\
\text { other thought }\end{array}$ & $\begin{array}{l}\text { Sen düşüncelerin ile hayata ne } \\
\text { güzel yaraşırdın }\end{array}$ \\
\hline $\begin{array}{l}\text { Sevmekten başka beni (ve, } \\
\text { benim tarafimdan) }\end{array}$ & (6)Than to love and be loved by me & $\begin{array}{l}\text { Sevmek ve benim tarafindan } \\
\text { sevilmekti senin adın }\end{array}$ \\
\hline $\begin{array}{lcc}\text { O çocuk ben } & \text { çocuk, } \\
\text { memleketimiz }\{-T U\} & \end{array}$ & (7)I was a child and she was a child & $\begin{array}{l}\text { Ben bir çocuktum bir zaman ve } \\
\text { sen o çocukluğumdaydın }\end{array}$ \\
\hline O deniz ülkesiydi & (8)In this kingdom by the sea & $\begin{array}{l}\text { Deniz ülkesinde } \\
\text { ağırlyordun }\end{array}$ \\
\hline $\begin{array}{l}\text { Sevdalı } \\
\text { karasevdalıydık }\end{array}$ & & \\
\hline Ben ve Annabel Lee (benim) & (9)I and my Annabel Lee; & Ben ve sen Annabel Lee (benim) \\
\hline $\begin{array}{l}\text { Göklerde uçan melekler (aşk } \\
\text { ile, cennet) }\end{array}$ & $\begin{array}{l}\text { (10)With a love that the winged } \\
\text { seraphs of heaven }\end{array}$ & $\begin{array}{l}\text { Bir aşk ile o cennetin kanatlı perisi } \\
\text { (leri) }\end{array}$ \\
\hline Kıskanırlardı bizi (beni ve onu) & (11)Coveted her and me. & $\begin{array}{l}\text { Seninle bendim } \\
\text { imrenileni }\end{array}$ aşkın \\
\hline $\begin{array}{l}\text { Bir gün işte bu yüzden göze } \\
\text { geldi (sebep) }\end{array}$ & $\begin{array}{l}\text { (12)And this was the reason that, } \\
\text { long ago }\end{array}$ & Ve bu, uzun zaman öncesiydi (sebep) \\
\hline O deniz ülkesinde & (13)In this kingdom by the sea & $\begin{array}{l}\text { Günlerin geçtiği yer deniz } \\
\text { ülkesiydi, }\end{array}$ \\
\hline $\begin{array}{l}\text { Üşüddü bir rüzgârından bulutun } \\
\text { (bir, dondurucu, esmek) }\end{array}$ & $\begin{array}{l}\text { (14)A wind blew out of a cloud, } \\
\text { chilling }\end{array}$ & $\begin{array}{l}\text { Ürpertici bir rüzgar, patlayan bir } \\
\text { bulut (esmek) }\end{array}$ \\
\hline Güzelim Annabel Lee & (15)My beautiful Annabel Lee & Ah güzelim Annabel Lee \\
\hline Götürdüler el üstünde & $\begin{array}{l}\text { (16)So that her highborn kinsman } \\
\text { came }\end{array}$ & Soylu akraban geldi gizlice \\
\hline $\begin{array}{l}\text { Koyup gittiler beni } \\
\text { (ve onu benden uzaklaştırdılar) }\end{array}$ & (17)And bore her away from me & Ve seni benden uzaklaştırdı sinsice \\
\hline Mezarı oradadır şimdi & (18)To shut her up in a sepulchre & $\begin{array}{l}\text { Asıl amacı aşkıma hüküm } \\
\text { giydirmekti }\end{array}$ \\
\hline
\end{tabular}




\begin{tabular}{|c|c|c|}
\hline $\boldsymbol{O}$ deniz ülkesinde & (19)In this kingdom by the sea & $\begin{array}{l}\text { Burası adı duyulmamış deniz } \\
\text { ülkesiydi }\end{array}$ \\
\hline $\begin{array}{ll}\text { Biz daha } & \text { bahtiyardık } \\
\text { meleklerden } & \text { (cennet,çok, } \\
\text { içinde,yarısı, değil) } & \end{array}$ & $\begin{array}{l}\text { (20)The angels, not half so happy in } \\
\text { heaven }\end{array}$ & $\begin{array}{l}\text { Periler, cennet yarısı kadar mutlu } \\
\text { değildi }\end{array}$ \\
\hline $\begin{array}{l}\text { Onlar kıskanırdı bizi (onu ve } \\
\text { beni) }\end{array}$ & (21)Went envying her and me & \\
\hline $\begin{array}{l}\text { Evet! Bu yüzden 'Şahidimdir } \\
\text { herkes ve deniz ülkesi' }\end{array}$ & $\begin{array}{l}\text { (22)Yes!- that was the reason (as all } \\
\text { men know) }\end{array}$ & $\begin{array}{l}\text { Deniz ülkesi insanlarından } \\
\text { kaçıracaktım sevgini }\end{array}$ \\
\hline 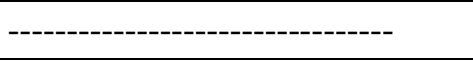 & (23)In this kingdom by the sea & 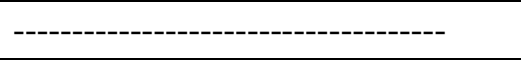 \\
\hline $\begin{array}{l}\text { Bir gece rüzgârından bulutun } \\
\text { (belirmek) }\end{array}$ & $\begin{array}{l}\text { (24)That the wind came out of the } \\
\text { cloud by night }\end{array}$ & $\begin{array}{l}\text { İşte ürpertici rüzgâr, gece ve bulut } \\
\text { (bir, belirmek) }\end{array}$ \\
\hline $\begin{array}{l}\text { Üşüdü gitti Annabel Lee (ve, } \\
\text { ölmek, benim) }\end{array}$ & $\begin{array}{l}\text { (25)Chilling and killing my Annabel } \\
\text { Lee }\end{array}$ & $\begin{array}{l}\text { Annabel Lee öldürecekler } \\
\text { biliyorum seni (ve, benim) }\end{array}$ \\
\hline $\begin{array}{l}\text { Sevdadan yana kim olursa } \\
\text { olsun }\end{array}$ & $\begin{array}{l}\text { (26)But our love it was stronger by } \\
\text { far than the love }\end{array}$ & $\begin{array}{l}\text { Bizim sevgi ve aşkımız çok daha } \\
\text { güçlü bilmiyorlar ki (fakat) }\end{array}$ \\
\hline Yaşca başca ileri & (27)Of those who were older than we & Daha biz birlikte yaşlanacağız \\
\hline Geçemezlerdi bizi & (28)Of many far wiser than we & Daha biz, daha biz of \\
\hline $\begin{array}{l}\text { Ne yedi kat göklerdeki } \\
\text { melekler }\end{array}$ & $\begin{array}{l}\text { (29)And neither the angels in } \\
\text { heaven above }\end{array}$ & $\begin{array}{l}\text { Çağırıyorlar yukarıda cennette } \\
\text { melekler, }\end{array}$ \\
\hline Ne deniz dibi cinleri & $\begin{array}{l}\text { (30)Nor the demons down under the } \\
\text { sea }\end{array}$ & En aşağıda deniz altında iblisler, \\
\hline Hiçbiri ayıramaz beni senden & $\begin{array}{l}\text { (31)Can ever dissever my soul from } \\
\text { the soul }\end{array}$ & $\begin{array}{l}\text { Ruhundan ruhumu koparmak } \\
\text { isteyecekler }\end{array}$ \\
\hline Güzelim Annabel Lee & (32)Of the beautiful Annabel Lee & Ah güzelim Annabel Lee \\
\hline Ay gelir ışır, hayalin erişir & $\begin{array}{l}\text { (33)For the moon never beams } \\
\text { without bringing me dreams }\end{array}$ & $\begin{array}{l}\text { Ay bana hayallerini eriştirir gün be } \\
\text { gün }\end{array}$ \\
\hline & (34)Of the beautiful Annabel Lee & Ah güzelim Annabel Lee \\
\hline & $\begin{array}{l}\text { ars never rise, but I } \\
\text { es }\end{array}$ & $\begin{array}{l}\text { Ve yıldızlar ile düşüncelerin bana } \\
\text { yükselir gün be gün }\end{array}$ \\
\hline & & $\begin{array}{l}\text { O parlak gözlerin hislerime } \\
\text { sürgün }\end{array}$ \\
\hline Güzelim Annabel Lee & (36)Of the beautiful Annabel Lee & Güzelim Annabel Lee \\
\hline $\begin{array}{l}\text { Orda gecelerim uzanır } \\
\text { beklerim }\end{array}$ & $\begin{array}{l}\text { (37)And so, all the night-tide, I lie } \\
\text { down by the side }\end{array}$ & Bütün gece med ve cezir \\
\hline $\begin{array}{l}\text { Sevgilim, sevgilim, hayatım, } \\
\text { gelinim }\end{array}$ & $\begin{array}{l}\text { (38)Of my darling- my darling- my } \\
\text { life and my bride }\end{array}$ & $\begin{array}{l}\text { Sevgilim, sevgilim, benim hayatım ve } \\
\text { ruh eşim, }\end{array}$ \\
\hline O azgin sahildeki & (39)In the sepulchre there by the sea & Deniz orada türbemizin içinde \\
\hline Yattığın yerde seni & (40)In her tomb by the sounding sea & $\begin{array}{l}\text { Sesleniyor } \\
\text { mezarimizdan } \\
\text { herkese }\end{array}$ \\
\hline
\end{tabular}

Tablo 1. Çeviri şiirlerin asıl metin ile karşılaştırması

\begin{tabular}{|l|l|l|}
\hline Dilbilimsel Olay & Melih Cevdet ANDAY & Uğur DEMİRöZ \\
\hline Biçimbirim Ekleme & $8,19,22$ & $2,6,16,25,39$ \\
\hline
\end{tabular}




\begin{tabular}{|l|l|l|}
\hline Biçimbirim Eksiltme & 7 & - \\
\hline Biçimbirim Değiştirme & - & - \\
\hline Sözcükbirim Ekleme & $\begin{array}{l}6,7,8,18,19,20,21,22,24,29,33,37, \\
39,40\end{array}$ & $\begin{array}{l}1,3,4,6,7,13,14,16,17,24,25, \\
26,29,31,33,35,\end{array}$ \\
\hline Sözcükbirim Eksiltme & $\begin{array}{l}3,5,6,9,10,14,18,19,20,24,25,27, \\
29,37,39,40\end{array}$ & $9,10,12,14,24,29,37$ \\
\hline Sözcükbirim Değiştirme & $11,13,14,40$ & $9,10,17$ \\
\hline Sözdizimsel Ekleme & $8-9$ aras1 & $35-36$ arasl, \\
\hline Sözdizimsel Eksiltme & $23,34,35$ & 21,23 \\
\hline Sözdizimsel Sapma & - & - \\
\hline Anlambilimsel Sapma & $12,16,17,26,28,33$ & $\begin{array}{l}11,5,8,18,19,21,22,26,27,28, \\
30,33,35,39,40\end{array}$ \\
\hline
\end{tabular}

Tablo 2. Erek metinlerdeki dilbilimsel olayların şairlere ve dizelere göre dağılımı

Tablo 2'de Anday ve Demiröz'ün çevirilerinin Poe'nun çevirisi ile olan farklılıkları ekleme ve sapma düzeyinde kalın punto ile gösterilmiş; kaynak metinde olduğu halde erek dilde yansıtılmayan sözcükbirimler ise parantez içerisinde italik punto ile belirtilmiştir. Tablo 3 incelendiğinde Anday'ın en çok sözcükbirim eksiltme ve eklemeye başvurduğu, en az biçimbirim eklemeye başvurduğu; Demiröz’ün ise en çok sözcükbirim ekleme ve anlambilimsel sapmaya, en az sözdizimsel eksiltmeye başvurduğu görülmektedir. Anlambilimsel sapmaların fazla oluşu Demiröz'ün çevirisinin asıl metinden fazlasıyla uzaklaşmasına neden olmuştur. 15., 32., 36. ve 38. dizeler iki şair için de kabul edilebilir düzeydedir. 1., 2., 30. ve 31. dizeler Anday için; 34. dize Demiröz için kabul edilebilir olarak değerlendirilebilir (bkz. Tablo2).

Poe’nun şiiri 6 bölüm, 40 dizeden; Anday'ınki 5 bölüm 36 dizeden; Demiröz'ünki 37 dizeden bölümsüz biçimde oluşturulmuştur. Anday ve Demiröz şiirlerinde serbest ölçüyü tercih etmişlerdir. Anday'ın çevirisinin göndergesel çerçeveyi değiştirmesi açısından ayrışık işlevli ve içerik bağımlı bir çeviri olduğu söylenebilir. Kayma sayısı daha az olan Anday, metin türü, metin konusunun uygunluğu, üslubu, kipi ve biçemi konusunda erek kültür normlarına bağlı olduğu için türdeş bir çeviri ortaya çıkarmıştır. Anday'ın erek odaklı kararları çevirinin çağrı ve ilişki işlevini yerine getirerek kaynak metnin göndergesel işlevini erek ekine uygun olarak değiştirmiştir. Bu noktada şairin amacına ulaşması ve erek ekine farklı bir bakış açısı kazandırması nedeniyle erek ekinde işlevini yerine getirdiği söylenebilir. Kaynak metne çok yaklaştığı için Demiröz'ün çevirisi ise eşdeğerlik açısından zaman zaman yeterli sayılabilecekken, erek dile olan uzaklığı nedeniyle kabul edilebilirlik düzeyinde ve belgesel çeviri niteliğinde değerlendirilebilir. Kaynak dilbilgisi kuralları erek dilin de bir getirisi olarak her iki şair tarafından da zaman zaman çiğnenmiştir. Dil dizgesi bakımından hatalı kabul edilebilecek kullanımlar ise olasılıkla kaynak metindeki ritmi sağlamak amacıyla ortaya çıkmıştır. Ulamsal ve anlamsal değiştirimler iki şairde de bulunmasına rağmen Demiröz'de daha fazla dikkati çekmektedir. Genel olarak Demiröz’ün çevirisinde esnek bir tutum takındığı söylenebilir. İçerik ve anlam boyutuna Anday'ın çevirisinde daha sadık kalındığını söylemek mümkündür. Demiröz'ün çevirisinde sözdizimsel, biçimbilimsel, sözcüksel ve anlambilimsel kaymalarının daha fazla olduğu, anlam açısından Türkçeye yabancı düşen dizeleri çevirmekte zorlandığı, zaman zaman tümceleri kaynak metindeki anlamına uygun olarak çevirmediği görülmektedir. Anday'da dizeler akıcı bütünlüğü sağlarken Demiröz'de estetik kaygılar fazlasıyla bulunduğu dikkati çekmektedir. Devrik tümcelere şiirin edebi doğası gereği başvurulduğu 
düşünüldüğünde bu bir eksiklik olarak görülmemiştir. Bu nedenle değerlendirmelerde sözdizimsel sapma ulamı kaynak ve erek dilin yapısal farklılıkları ve yazın metinlerinin süslü doğası gereği değerlendirme dışında tutulmuştur. Kimi zaman sapmalarla da olsa Anday'ın çevirisinin şiirin lirizm kokan havasını erek dile daha başarılı biçimde taşıdığı görülmektedir.

Aksan (2016)'a göre bir şiiri başarıyla başka dile aktarmak metne sadık biçimde çevirmekle değil kendi dilinde yeniden yazmakla mümkündür. İncelenen çevirilerde de bu ölçütü Anday'ın sağladığını söylemek yanlış olmayacaktır. André Lefeveré’e göre Anday şiir çevirisinde yorumlama ve serbest koşuk izlemini; Demiröz ise birebir, yorumlama ve serbest koşuk izlemini kullanmıştır. Nida’ya göre Anday biçimsel ve devingen eşdeğerliği sağlarken; Demiröz'ün sadece biçimsel eşdeğerliği sağladığı söylenebilir. Popovic'e göre, Anday dilsel, dizisel ve biçemsel eşdeğerliği fazlasıyla yerine getirmekte; Demiröz'ün ise çok fazla eksiklerinin olduğu görülmektedir; fakat metinsel eşdeğerlik iki şairde de sağlanmıştır. Popovic'in deyiş kaydırmaları açısından bakıldığında Anday'da bireysel kaymalar olmasına rağmen metnin anlamını koruduğu; Demiröz'ün ise çoğu zaman konusal kayma, olumsuz kayma ve bireysel kaymaya uğradığı açıktır. Her iki şair için de dil dizgesinden kaynaklı yapısal kaymalar erek dilin yapısı gereği olduğu için göz ardı edilebilir. Koller açısından ise Anday'da düzanlamsal, yananlamsal, edimsel ve biçimsel eşdeğerlik sağlanırken; Demiröz'de ihmal edilmiştir. Vinay ve Darbelnet'e göre ise iki şairin de uyarlama, zorunlu/isteğe bağlı yer değiştirme ve zorunlu/isteğe bağlı modülasyon aşamalarından geçerek şiiri çevirdikleri söylenebilir. Jakobson'a göre çeviriler diller arası çeviri örneği sergilerken; House'un bakış açısına göre Anday'ın çevirisinin kendine has üslubu, sözcükleri şiirsel bir hava ile uyumlu biçimde bir araya getirmesi nedeniyle örtük çeviriye daha yakın olduğu, Demiröz’ün ise çeviri metninde erek dil hâkimiyetinin yeterli olmaması nedeniyle hedef dilde beklenen uyum ve aktarımı yakalayamamasından dolayı açık çeviriye yakın olduğu söylenebilir. Newmark açısından bakıldığında Anday'ın çevirisinin iletişimsel; Demiröz'ün ise anlamsal olduğu söylenebilir. Cattford açısından ise düzey kaymaları ve dilbilgisel kaymalar her iki şairde olsa da Demiröz'ün çevirisinde daha yoğun hissedilmektedir.

\section{Sonuç ve öneriler}

Şiir çevirisi yoruma dayalı üst dilsel bir işlem olması nedeniyle her çevirinin farklı bir yöntemi ve işlevi vardır. Anday'ın çevirisinin içeriğe dayalı bir çeviri olması nedeniyle biçimi yakalayarak «ayrışık işlevli» bir çeviri örneği oluşturduğu söylenebilir. Demiröz’e oranla kayma sayısının daha az olması onun kaynak metne daha yakın «türdeş işlevli» bir çeviri ürettiğini gösterir. Anday'ın çevirisinin hem kaynak şairin amacına ulaşması hem erek dilde yeni bir bakış açısı kazandırması nedeniyle erek dildeki işlevini yerine getirdiği söylenebilir. Demiröz’ün çevirisinin ise kaynak metne fazlasıyla sadık kalması nedeniyle Nord'a göre «belgesel çeviri» sınıfına girerek «betikbilimsel işlevi» yerine getirdiği söylenebilir.

İki çevirmen de farklı izlemler doğrultusunda çeviri yöntemleri kullanmışlardır. Anday, kaynak metne bağlı kalma ve kültürel özgünlüğü koruma kaygısı ile sözcüğü sözcüğüne çeviri yöntemini, Demiröz ise daha çok serbest çeviri yöntemini tercih etmiştir. Anday, metne bağlılıktan ziyade metnin işlevini ve etkisini dikkate alarak göstergelerin erek dildeki karşılığını bulmaya çalışmıştır. Yer yer diğer çeviri yöntemlerine başvursalar da iki şair de daha çok yorumlama, uyarlama ve denklik yöntemlerini yeğlemişlerdir. Kaynak dildeki anlatımı erek dilde yer yer iki çevirmen de sağlayamamıştır. Bunun sonucunda anlaşılan ama zaman 
zaman erek dil okuyucusunun sınırlarını zorlayan bir dil ve anlatım ortaya çıkmıştır. İki dilde de gösteren düzleminde dil ailelerinden kaynaklı farklılıklar çok fazladır. Fakat buna rağmen Anday'ın çevirisinde kaynak dilde hissedilen duygunun erek dilde de hissedildiğini söylemek mümkündür. Dilbilgisel, biçimbilimsel, sözdizimsel, sözcüksel, anlambilimsel sapmalarla da olsa kaynak metindeki etkinin erek dilde Anday'ın çevirisiyle daha başarılı biçimde sağlandığını belirtmek yanlış olmayacaktır. Demiröz’ün çevirisinden onun İngilizceye yeteri kadar vakıf olmamasının yanı sıra şair yönünün de Anday kadar güçlü olmadığı ve kaynak metni erek dile uygun biçimde yorumlayarak bütünleştiremediği anlaşılmaktadır. Anday’ın erek dile ve kültürel kullanımlara daha fazla hâkim olması sayesinde kaynak ve erek metnin hedef kitlelerinin dil dizgeleri farklı olsa da şiirden benzer tatları alacakları söylenebilir.

İyi bir şair kaynak dile, erek dile ve her iki kültüre de hâkimdir. Ayrıca kaynak metinde yer alan ifadeleri dilin esnekliğinden yararlanarak deyim ve atasözleri ile zenginleştirebilme yetisine sahiptir. Usta kalemler geniş kitlelere ulaşarak okuyan/dinleyende estetik haz uyandırır ve yansıttığı sanat eserine gereken değer verilerek hedef kitle tarafından rağbet görür. Bu nedenle usta şairlerin elinden geçen şiirler daha bir başkadır. Anday'ın çevirisinde de bu ustalığı görmek mümkündür.

Bu sonuçlar dâhilinde çeviribilim alanında dilbilimsel uygulamalar için şu önerilerde bulunulabilir:

1. Dilbilimin çeviribilime bilimsellik ölçütleri kazandırarak bir bilim dalı olarak gelişmesine olan katkısı çeviribilim çalışmalarında göz ardı edilmemelidir.

2. Çeviri çalışmaları dilbilimden soyutlanmamalı ve incelemeler disiplinlerarası yöntemlerle yapilmalıdir.

3. Çeviribilim bölümlerinde ve kaynaklarında dilbilimin kuram, yöntem ve tekniklerinden istifade edilmelidir.

4. Çeviribilim bölümlerindeki dilbilim derslerinin türleri artırılmalı ve içeriği zenginleştirilmelidir. Aynı şekilde dilbilim bölümlerinde de çeviribilim dersleri mutlaka yer almalıdır.

5. Çeviribilimle ilgili konu ve sorunlarda dilbilimcilere de danışılmalıdır. Özellikle edebi ürünler çevrildikten sonra bir dilbilim uzmanının da görüşü alınmalıdır.

6. Dil öğretimi ile ilgili her kademeden edebi kitap/ ders kitabı için edebi ve duygu yönünün güçlülüğü nedeniyle öğrencide estetik haz uyandırabilmeł amacıyla usta şairlerin çevirilerine yer verilmelidir.

\section{Kaynakça}

Aksan, D. (2007). Her yönüyle dil ana çizgileriyle dilbilim. Ankara: TDK.

Aksan, D. (2016). Şiï dili ve Türk şïr dili. Ankara: Bilgi.

Aslan, O. (2000). Bir çeviri örneği ve onun çeviri eleştirisinin ortaya koyduğu gerçekler.

Çeviri eleştirisi içinde. (Haz. Mustafa Durak). Ankara Üniversitesi Tömer Bursa Şubesi Sempozyum Bildirileri. Bursa, 52-61.

Aydın, M. (2014). Dilbilim el kitabı. İstanbul: Sözcü.

Başaran, M. A. (2013). Şiir çevirisinde sözdizimsel eşdeğerlik. International Journal of Language Academy, 1 (1), 91-105.

Başkan, Ö. (1978) Dilde çeviri işlemi, Türk Dili Aylık Dil ve Yazın Dergisi, 322, 26-36. 
Baytekin, B. (2000). Günter Grass'in "Die Blechtrommel" romanının Türkçeye çevirisinde atasözleri, deyimler ve özdeyişlere eleş̧tirel yaklaşım. Çeviri eleştirisi içinde. (Haz. Mustafa Durak). Ankara Üniversitesi Tömer Bursa Şubesi Sempozyum Bildirileri. Bursa, 62-74.

Boztaş, İ. (1993). Çeviri, çevirmen, dilbilim ilişkisi, çeviride eşdeğerlik ve kayıplar, Hacettepe Üniversitesi Edebiyat Fakültesi Dergisi, 10 (2), 55-65.

Büyüköztürk vd. (2016). Bilimsel araştırma yöntemleri. Ankara: Pegem.

Çetinkaya, S. (2017). Çevirinin dilbilim ve yazınbilim ile ilişkisi. Journal of Social and Humanities Sciences Research, 4 (5), 1228-1223.

Delibaş, M. ve Delibaş, H. (2017). "Veba" adlı eser ile Türkçe çevirilerinin karşılaştırılmalı çözümlenmesi. International Journal of Languages’ Education and Teaching, 5 (3), 568-578.

Demiral, S. ve Kaya, M. (2013). Şiir çevirilerinde karşılaşılan sorunlar ve çözüm önerileri. Turkish studies, 8 (10), 251-264.

Göktürk, A. (2019). Çeviri dillerin dili. İstanbul: Yapı Kredi Yayınları.

Hengirmen, M. (1999). Dilbilgisi ve dilbilim terimleri sözlüğü. Ankara: Engin.

Jakobson, R. (1959). On linguistic aspects of translation. In on translation.

Cambridge: Hardvard University Press.

Karaağaç, G. (2013). Dil bilimi terimleri sözlüğü. Ankara: TDK.

Karavin, H. (2016). Çeviri Kuramları bağlamında eşdeğerlik kavramının izini sürmek,

Trakya Üniversitesi Edebiyat Fakültesi Dergisi, 6 (12), 125-144.

Kocaman, A. (1993). Çeviri, çeviri eleştirisi, dilbilim. Dilbilim Araştırmaları, 4, 1-4.

Köksal, D. (2008). Çeviri eğitimi kuram ve uygulama. Ankara: Nobel.

Köktürk, Ş. (2015). Uygulamah çeviribilim. Ankara: Detay.

Malmkjaer, K. (2005). Translation and linguistics. Perspectives: Studies in Translatology, 3 (1), 4-20.

Özdemir, İ. (2014). Edgar Allen Poe'nun "Annabel Lee" adlı şiirinin Melih Cevdet Anday tarafından yapılan çevirisine eleştirel bir çözümleme. Ana Dili Eğitimi Dergisi, 2 (4), 16-31.

Özek, F. (2001). Cahit Sıtkı Tarancı'nın Ölümden Sonra Adlı şiirinin dilbilimsel açıdan incelenmesi. Furat Üniversitesi Sosyal Bilimler Dergisi, 11 (2), 147-164.

Stolze, R. (2013). Çeviri kuramları. (çev. Emra Durukan). İstanbul: Değişim.

Tahir Gürçağlar, Ş. (2019). Çevirinin ABC'si. İstanbul: Say

Uygur, N. (1989). Dilin gücü. (3.baskı). Ankara: Ara yayıncllı.

Ülsever, Ş. (2007). Karşılaştırmah edebiyat ve edebi çeviri. Eskişehir: Osmangazi Üniversitesi Yayınları.

Vardar, B. (1988). Açıklamalı dilbilim terimleri sözlüğü. İstanbul: ABC.

Vardar, B. (2001). Dilbilim yazıları. İstanbul: Multilingual.

Yazıcı, M. (2005). Çeviribilimin Temel Kavram ve Kuramları. İstanbul: Multilingual.

Yıldırım, A. ve Şimşek, H. (2011). Sosyal bilimlerde nitel araştırma yöntemleri. Ankara: Seçkin.

Yılmaz, S. (2013). Yaşar Kemal'in “İnce Memed” romanı ile Fransızca çevirisi üzerine dilbilim ve çeviri incelemesi. Turkish Studies, 8 (10), 743-754.

https://www.siir.gen.tr/siir/e/edgar_allan_poe/annabel_lee.htm erişim:20.06.2019

https://www.siirleraslabitmemeli.com/annabel-lee-edgar-allan-poe-siir-cevirisi/ erişim:20.06.2019 